\title{
Late presentation of hypertrophic cardiomyopathy with apical aneurysm
}

\author{
Vinit Sawhney, ${ }^{1,2}$ Oksana Maksunova, ${ }^{1}$ Fahad Iqbal, ${ }^{1}$ Mark Westwood ${ }^{1,2}$
}

${ }^{1}$ Department of Cardiology, North Middlesex University Hospital NHS Trust, London, UK

${ }^{2}$ Barts Heart Centre, London, UK

\section{Correspondence to} Dr Vinit Sawhney, sawhneyvin@googlemail.com

Accepted 13 December 2016

\section{DESCRIPTION}

The present image shows an echocardiogram depicting a large left ventricular (LV) apical aneurysm $\left(20 \mathrm{~cm}^{2}\right)$ with spontaneous contrast (figure 1; cine images are provided as videos 1 and 2) in a patient with hypertrophic cardiomyopathy (HCM) whose first presentation was in the seventh decade of her life. The patient presented with a history of dyspnoea and was in periarrest ventricular tachycardia (VT) in the emergency department. Five DC shocks were unsuccessful and she eventually cardioverted with intravenous amiodarone.

An angiogram showed unobstructed coronary arteries. CMR confirmed LV apical aneurysm along-with moderate septal hypertrophy with maximum wall thickness of $1.7 \mathrm{~cm}$ and evidence of midcavity obliteration. A family history of SCD and HCM (with confirmed genetics) was

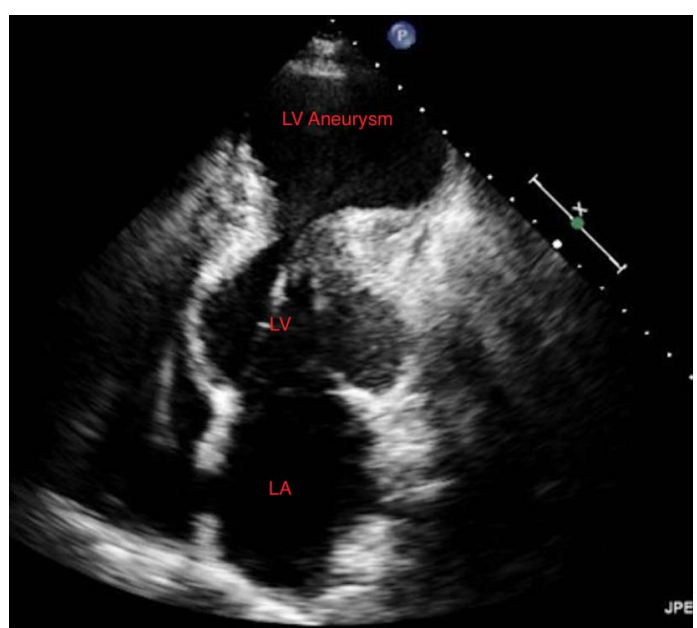

Figure 1 Large left ventricular apical aneurysm in hypertrophic cardiomyopathy presenting with ventricular tachycardia.

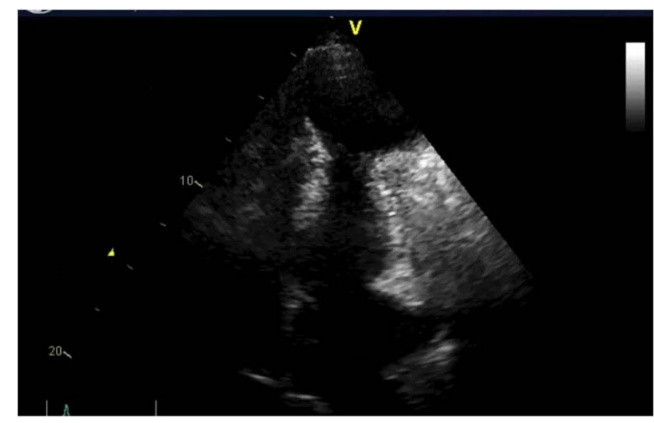

Video 1 Left ventricular apical aneurysm in hypertrophic cardiomyopathy.

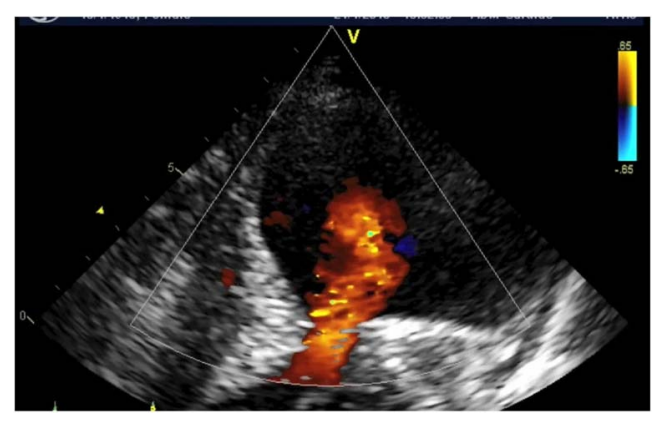

Video 2 Colour flow across the neck of left ventricular apical aneurysm in hypertrophic cardiomyopathy.

established. Based on her presentation, cardiac imaging and family history, a diagnosis of familial HCM was made.

The vast majority of patients with HCM present in the third to fifth decade of life and late presentations, as in our case, are rare. LV apical aneurysms in the absence of coronary artery disease is an under-recognised subgroup of patients with $\mathrm{HCM}^{1}$ This HCM pattern is associated with poor clinical outcomes, including sudden death, embolic stroke and progressive heart failure. ${ }^{2}$ Clinical recognition of this phenotype requires a high degree of suspicion and an echocardiogram might not always be the most sensitive method to delineate apical aneurysms. ${ }^{3}$ Timely recognition of patients with HCM with LV apical aneurysms can alter clinical practice by triggering consideration for primary prevention of sudden death with an implantable defibrillator and prophylactic anticoagulation in patients with larger aneurysms.

\section{Learning points}

- First presentation of patients with hypertrophic cardiomyopathy (HCM) can be late and it is not solely a disease of young adults.

- Left ventricular apical aneurysms in HCM are rare and associated with poor prognosis.

- Timely recognition is vital for patient management and family screening.

Contributors VS is responsible for concept and writing manuscript. $\mathrm{OM}$ is responsible for obtaining echo images. $\mathrm{Fl}$ is responsible for obtaining consent from the patient. MW is responsible for concept and reviewing the manuscript.

Competing interests None declared.

Patient consent Obtained. 
Provenance and peer review Not commissioned; externally peer reviewed.

\section{REFERENCES}

1 Fujino $\mathrm{N}$, Konno $\mathrm{T}$, Yamagishi $\mathrm{M}$, et al. Left ventricular apical aneurysm and systolic dysfunction in hypertrophic cardiomyopathy. J Cardiol 2014;64:253-5.
2 Ennezat PV, Mouquet F. Hypertrophic cardiomyopathy associated with left ventricular apical aneurysm. Arch Cardiovasc Dis 2010;103:198-9.

3 Morita Y, Kato T, Okano M, et al. A rare case of hypertrophic cardiomyopathy with subendocardial late gadolinium enhancement in an apical aneurysm with thrombus. Case Rep Radiol 2014;2014:780840.

Copyright 2017 BMJ Publishing Group. All rights reserved. For permission to reuse any of this content visit

http://group.bmj.com/group/rights-licensing/permissions.

BMJ Case Report Fellows may re-use this article for personal use and teaching without any further permission.

Become a Fellow of BMJ Case Reports today and you can:

- Submit as many cases as you like

- Enjoy fast sympathetic peer review and rapid publication of accepted articles

- Access all the published articles

- Re-use any of the published material for personal use and teaching without further permission

For information on Institutional Fellowships contact consortiasales@bmjgroup.com

Visit casereports.bmj.com for more articles like this and to become a Fellow 